\title{
Лингвистика
}

\author{
УДК 811.161.1,373.2
}

\section{С.Г. Шейдаева}

\section{ЛЕКСИКА ЯМСКОГО И ИЗВОЗНОГО ПРОМЫСЛОВ: ИСТОРИКО-СЛОВООБРАЗОВАТЕЛЬНЫЙ АСПЕКТ}

В статье на материале памятников русской деловой письменности XVI-XVII вв. рассматриваются семантические и словообразовательные особенности лексики ямского и извозного промыслов. В содержательном плане слова этих двух профессиональных сфер имеют много общего, так как основным занятием ямщиков и извозчиков была перевозка людей или грузов на лошадях; здесь используются наименования действующих лиц, транспортных средств, способов передвижения, видов перевозимых объектов. История закрепления слов ямщик и извозчик в русском языке отражает универсальную закономерность смены названий лиц на -ник существительными на -щзикчик (ямник - ямщзик, извозник - извозчик). В то же время категориальное различие исходных имен, находившихся в начале словообразовательных цепочек, обусловило разницу в семантическом развитии наименования деятелей: в одном случае это пространственная номинация ям «станция на дороге» (> ямчи, ямской > ямщзик), в другом - обозначение передвижения в пространстве изво́зити (> извоз > извозчик). В связи с этим названия лиц изначально расходились в концептуальных представлениях об этих деятелях: ямщзик - тот, кто передвигается по дороге, а извозчик - «возит» и по земле, и по воде (подобно перевозчику). В разных коммуникативных сферах ямского (гонного) и извозного промыслов сложились специфические названия перевозок - гоньба и извоз, которые имели ясную внутреннюю форму: первое было мотивировано глаголом гоняти «очень быстро ездить», второе - глаголом извозити «вывозить» (грузы, товары).

Ключевые слова: история русского языка, лексика ямского и извозного промыслов.

DOI: 10.35634/2412-9534-2021-31-6-1127-1142

Данная статья является продолжением исследования лексики крестьянских промыслов на материале памятников русской деловой письменности XVI-XVII вв. Основным источником фактического языкового материала стал «Словарь русского языка XI-XVII вв.», который «дает возможность составить полную картину словарного богатства русского языка различных исторических эпох, проследить историю русского слова, установить его семантическое развитие и деривационные связи на протяжении длительного исторически засвидетельствованного периода развития русского языка [36, с. 137]. Источниками языковых фактов послужили и другие исторические словари, а также тексты памятников деловой письменности и работы русских историков.

Лексика ямского и извозного промыслов, как она представлена в текстах XVI-XVII вв., отражает деятельность человека, связанную с перевозкой кого-чего-либо на лошадях. В этой сфере родились прототипы многих устойчивых выражений: «не понукай, не запряг», «натянул вожжи», «вожжа под хвост попала», «ругается как извозчик», «поворачивай оглобли», «не в своей колее» и др. Некоторые современные слова также оказываются связанными с этой лексикой: гонка (предвыборная, спортивная) исторически стоит в одном ряду со словом гоньба (ямская), а, например, выражение «подмена понятий» - с подменой лошадей на почтовой станции.

Занятие ямщиков и извозчиков отличалось от обычных крестьянских промыслов, когда ремесленник сидел дома тачал сапоги, лудил кастрюли или выделывал кожу. Ямщики и извозчики гнали гоньбу, уходили в извоз - ямщзчали и извощичали по бескрайним просторам России. Но и это также являлось промыслом (от промыслити), то есть делом, занятием, приносящим доход (хотя в XVI в. часть ямщиков входила в особую социальную категорию служильхх людей).

В современной русской лигвокультуре представление о ямщике во многом сформировано так называемыми «ямщицкими» песнями: «Ямщик, не гони лошадей», «Эй, ямщик, гони-ка к Яру», «Когда я на почте служил ямщиком» и др. «Образ ямщика семантически коррелирует с «зимней, скучной» дорогой, звоном колокольчика, «печальными полянами» - пишут филологи [31].

Происхождение данного существительного связывают со словом ямъ - тюркским заимствованием XIII века. В «Материалах для словаря древнерусского языка» И.И. Срезневского это слово указано, как использующееся в ярлыках ханов Золотой Орды: «Не надобе имъ дань, и томга, и поплуж- 
ное, ни ямъ, ни подводы, ни воина, ни кормъ» (Ярл. Менг. Тем. 1267 г.), «Дань ли на насъ емлютъ, или иное что буди, тамга ли, поплужное ли, ямъ ли, мытъ ли..., а отъ соборныя цркви и отъ Петра митрополита никто же да не взимаетъ» (Ярл. Узб. 1315 г.) и др. [30] (орфография цитат из исторических источников здесь и далее дается в упрощенном виде). В этих древнейших контекстах, как это определяет сам автор словаря, слово ямъ имеет значение «ямская повинность, денежный сбор на ямскую гоньбу».

Этимологически это слово восходит, по данным М. Фасмера, к тюркскому јат в значении «почтовая станция, почтовые лошади» [35]. Татаро-монголы «еще в Азии устраивали для гонцов и послов особые станы, куда окрестные жители должны были доставлять лошадей и продовольствие», и слово ямъ происходит от дзямъ «дорога» [26, с. 800]. Устройство таких станций на Руси относится ко времени татаро-монгольского нашествия, «обеспечение их стоило больших средств, и с покоренных народов собиралась особая подать - "татарский ям" [14, с. 54]. Как это показано Срезневским, на русской территории слово ямъ первоначально обозначало ямскую повинность, денежный сбор [30], однако далее, в связи с тем, что «термин ям долго держался в русском языке» [37, с. 230], слово приобрело и другие значения, в частности - остановка на ямской дороге, селение, «коего крестьяне отправляют на месте почтовую гоньбу» [12].

C XVI в. последнее значение уже является единственным [37, с. 230]. В «Историкоэтимологическом словаре русского языка» П.Я. Черных ям определяется как сторожевой пункт, ведающий ямской гоньбой и предназначенный для смены лошадей [38]. Ямы, или ямщичьи стойки, в XVI-XVII вв. устраиваись по всей стране: «Из Москвы или из ближайшего города воеводами высылался служилый или приказный человек для устройства яма. «Стройщик» расписывал дорогу, по которой предполагалось устроить ямы, на станы, отстоявшие друг от друга на 40-50 верст, и к каждому стану относил ближайшее население по росписи, составленной на основании платежных книг» [42, с. 664].

В текстах начала XVII в. отражены устойчивые сочетания «стояти на яму», «сойти с яму», «на яму гоняют», а также отсылки к месту расположения того или иного яма, например: «Велел ты, государь, мне... охвотниковъ сыскати... што имъ стояти на яму с подводами под твои государевы скорые гонцы» (1585) [28, вып. 14, с. 85], «а жены ихъ и дети сошли съ яму безвистно ...на яму гоняють только восмь человекъ» (1600) [28, вып. 4, с. 78], «явился елецкого яму охотникъ Сава Нестеров» (1615) [25, с. 48], здесь «елецкий ям» - у г. Ельца.

В названиях разных реалий, относящихся к яму, использовалось прилагательное ямской: ямской приказ, приказчик, охотник, бобыль, ямская подвода, гоньба, слобода, книга, подать, ямское пятно (тавро у лошади), ямские деньги, сани и проч.

Ямской приказ, основанный в XVI в., «заведовал ямщиками, проверял гонебные книги, выдавал подорожные, а также ведал и почтовую часть, которая первоначально была в неразрывной связи с ямскою» [26, с. 800]. Пример из текста: «довелось вязьмичем, посадским людем, платить... в Ямской приказ ямских денег по 196 рублев» (1648) [4, с. 194]. Этот приказ существовал наряду с другими ведомствами, взимавшими «повинности». В одной челобитной посадские люди жаловались на то, что несмотря на данную им льготную грамоту, они «ни единаго году во льготе не жили, истоскали нас, сирот твоих, мимо вашу государеву жалованную грамоту из розных приказов, из Ямского приказу, из Большего Приходу, из Стрелецкаго приказу» (1645) [4, с. 122].

В приказах служили приказчики (приказные люди), в ямском приказе - ямские приказчики, которые в особых «загонных» книгах фиксировали имена проезжающих, проезжие грамоты, количество подвод и оплаченные прогоны [42, с. 664]. Например: «Отделили въ Обонежскои пятине ямскому прикащзику и охотникомъ... къ старой ихъ даче къ охотницкой земле 124 четверти въ поле» (1587) [28, вып. 14, с. 85].

Ямская повинность в XVII в. - это один из видов личных повинностей, то есть обязанностей крестьян выполнять работы безвозмездно и в принудительном порядке. «Повинность могла отбываться или всем населением и состояла в обязанности поставлять готовые подводы и проводников по требованиям правительства, или выполнялась нарочно для того выбранными ямщиками, устроенными правительством на особых землях в ямских слободах» [42, с. 664]. Эти люди назывались ямскими охотниками, или ямщиками. Их избрание из нетяглых, лучших людей закреплялось «выбором» (особым актом), в котором обозначались обязанности. Затем ямщик получал от населения подмогу «для двороваго и лошадинаго поставления» в виде денежной суммы и некоторого количества ржи и овса [42, с. 664]. Сами ямщики своей службой освобождались от податей. 
Охотник - от слова охота «желание, стремление»; охотою, своею охотою - значит «по доброй воле, добровольно» [28, вып. 14]. В ямщики поступали желающие, или охочие люди: «Велел ты, государь, мне... охвотниковъ сыскати... што имъ стояти на яму с подводами под твои государевы скорые гонцы» (1585) [28, вып. 14, с. 85], «А выписавъ подлинно..., как на ямехъ впередъ охотникомъ быти прочнее... и сколко... охотниковъ противъ прежнего ли, или которые старые охотники, избегая гонбы, живут въ бегахъ... о томъ бы есте о всемъ къ намъ подлинно отписали (1625) [28, вып. 4, с. 77]. По последнему контексту видно, что охотники могли и «терять охоту» к ямскому делу. Словосочетание ямской охотник устойчиво использовалось в деловых текстах первой половины XVII в., приведем примеры: «взят заповеди виннаи на емском охотнике на Федоре Шепеле» (1617) [23, с. 97], «Бьет челом... верхотурскои ямскои охотничишко Гришко Смокотнин» (1639) [28, вып. 14, с. 85].

Ямская повинность для населения состояла, прежде всего, в обязанности поставлять готовые

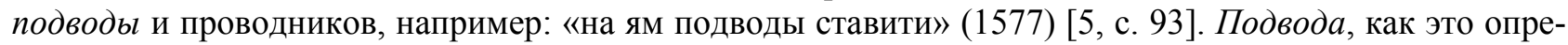
деляется в историческом словаре русского языка, - это «лошадь с верховой или вьючной упряжью; перекладная лошадь, поставляемая («подводимая») местными жителями князьям, гонцам, посланникам и др.» [28, вып. 16]. Указание на отглагольный характер производного (подвода < подводимая) проясняет функциональный статус внутренней формы имени и подтверждает его деэтимологизацию в современном языковом сознании, которая произошла в связи с утратой знания об исторической ситуации (в наше время подводы ассоциируются, скорее, с гружёными возами). В одном из деловых текстов начала XVII в. встречаем метонимическое сочетание «подводы померли»- о лошадях: «Подводы съ надсады, и съ безкормицы, и съ волокиты многия померли» (1622) [28, вып. 16, с. 236$].$

Устойчивое сочетание ямская подвода отражало конкретизацию понятия в данной сфере общения (подвода для ямской перевозки). Пример: «И дать им до Москвы ямские подводы и на нихъ прогоны, на чемъ имъ мочно поднятись» (1696) [28, вып. 13, с. 305]. Летом это были, как правило, телеги, зимой - сани. «Ямские сани делались низкие, длиною в рост человека, из лубков или липовой коры и выстилали толстым войлоком. Путник ложился в сани, сверху его покрывали овечьими шкурами» $[15$, с. 98$]$. Зимний путь, зимник - дорога, по которой ездят только зимой: «зимнимъ путемъ повезутъ больши тысячи рыбъ» (1596) [28, вып. 5 с. 389], «Дорогою зимникомъ отъ ели и оть дву осинъ на осину» (1601) [28, вып. 5 с. 389].

Самым показательным для этой сферы деятельности было, пожалуй, понятие о ямской гоньбе, то есть о ямской повинности вообще (ямщине) или о любой перевозке людей и грузов на лошадях [28, вып. 4]. Например: «твоие государевы службы, ямские гонбы, намъ охотничишкомъ на Бобровскомъ яму служити» (1633) [28, вып. 4, с. 77], «а верстатца... в ямской гонбе... меж себя по вся годы» (1644) [4, c. 39].

Семантические варианты слова гоньба, использовавшиеся на разных русских территориях, отражены в словаре под редакцией О.Н. Трубачева: гоньбой называлось «содержание ямской станции: ямщина, извоз» (енис., вят., том., кемер.), «повинность, возлагавшаяся на крестьян, обязанных представлять подводы для перевозки казенных грузов» (урал.), «частые разъезды» (вят.) и др. [41, вып. 7, c. 27]. Приведем также примеры из текстов XVII-XVIII вв.: «а для гонбы держати ямщикомъ по две лошади человеку» (1606) [28, вып. 4], «старые охотники, избегая гонбы, живут въ бегахъ» (1625) [28, вып. 4, с. 77], о лошадях - «чтоб они всегда были в сытости и к гонбе были готовы»» [28, вып. 4].

Это существительное нередко выступает в качестве компонента устойчивого словосочетания «гоньбу гоняти (оганивати)», например: «а гонбу за его выть гоняли все повытно охотники» (1602) [28, вып. 4], «И вместо беглых ямщиков выбылую их ямскую гонбу оганиваем мы миром в великои тягости» (1691) [28, вып. 12, с. 232]. Отметим также синонимическое устойчивое сочетание - «гонять ямщину»: «И стоять... в техъ местехъ где достанетца и гонять ямщину беспереводно не запуская своих подводъ» (1698) [28, вып. 5, с. 281]. А.М. Кошкарева, анализировавшая существительное гоньба, отмечает, что известное на территории Сибири и Урала устойчивое словосочетание гонять гоньбу означало «отбывать волостную или сельскую подводную повинность». Слово гоньба в значении «ямщина, извоз» было известно в говорах северных районов Тюменской области, но чаще употреблялся его эквивалент ямщиина [18, с. 32].

У глагола гонять в «Словаре русского языка XI-XVII вв.» фиксируется целый комплекс значений: и описанное выше специальное значение «заниматься ямской гоньбой, выполнять ямскую повинность», и общенародные значения «гонять, заставлять двигаться» (гонять на вылас), «преследовать» (за теми лихими гонял), «охотиться, травить зверя», «ездить быстро, разъезжать», «преследо- 
вать», «сплавлять» (лес, дрова) и др. [28, вып. 4]. Все эти значения различаются, прежде всего, тем, кто, с какой цуелью и с применением каких средств действует. В ситуации ямской гоньбы это ямщик, лошади (подвода) и заданная цель в конце пути. В иных специальных сферах складывались другие актантные структуры. Так, в истории лексики лесного сплава, где слово гнать означало «заставлять двигаться вплавь по течению реки лес, бревна, плоты», как пишет Г.Л. Гладилина, «конкретный объект действия, а именно лес, бревна, плоты становится постоянной принадлежностью лексического значения глагола гнать, функционирующего в подъязыке лесного сплава, что и обеспечивает семантический сдвиг и специализацию его значения» [10].

Итак, специализация глагола в сфере ямской гоньбы, как и любая конкретизация слова в узкой сфере общения, связана с изменением типа объекта и видом действия, названного глаголом. Здесь это «ямская гоньба», где гонят лошадей быстро, в заданном направлении и за плату. Глагол в конце концов утрачивает необходимость в зависимом слове, так как лошади - это константа, но главным всё же является само движение по дороге: гонять лошадей > гонять > гоньба. Е.П. Елисеева в статье «Из истории русской лексики почтовой связи» пишет: «Главным источником формирования рассматриваемой терминологии в данный период являются готовые лексические единицы, вовлеченные путем сужения, специализации значения (бежать «ехать быстро, верхом или упряжью», гнать «держать лошадей и ямщиков, заниматься гоньбой»; разгон «ямская гоньба, езда» [13, с. 27-28].

В рассматриваемых нами контекстах синонимом прилагательного ямской нередко выступает слово гонный, которое определяется как «относящийся к гоньбе» [28, вып. 4]. Показательно, что в памятниках русской письменности это прилагательное используется в сочетаниях с теми же существительными, что и ямской: «да Ямъски слободы гонъные охотники Богдан Ломакин...» (1618) [23, с. 106], «тоежъ гонные ямские слободыл» (1578), «...по большой гонной дороге на большомъ перевозе» (1623) [28, вып. 4]. Здесь отражены факты синонимической замены в парах ямские / гонные охотни$\kappa и$, ямские / гонные слободы, ямская / гонная дорога. В то же время в словообразовательном плане гонный было мотивировано не словом гоньба, а существительным гон. От слова гоньба было образовано прилагательное гонебный, например: «И сколько на которомъ яму гонебныхъ лошадей отъ повитрея пало» (1595) [28, вып. 4, с. 72].

От глагола гоняти в значении «выполнять ямскую повинность» активно образовывались префиксальные глаголы - перегоняти, прогоняти, загоняти и др., выражавшие разные стороны ямской гоньбы. Так, глагол перегоняти означал «превысить установленную повинность ямской гоньбы, переработать лишнее» [28, вып. 14, с. 228]. Он стал производящим для существительного перегон в значениях «ямская гоньба сверх установленной повинности» и «отрезок пути, на котором казенных ездоков перевозили на подводах, предоставляемых населением в порядке ямской повинности». Примеры из текстов: «И будеть те ямщики в те годы по своимъ книгам перегоняли и перегонь у ямъщиков есть, и вы б тем ямъщиком счетчи по их книгам те перегонь дали по ншему наказу» (1556), «ездятъ безпрестани, а перегоны велики, до Перми и до Соли Камской полтретьяста верстъ» (1614) [28, вып. 14, с. 228].

Помимо пары перегоняти > перегон существовала связка прогоняти «гнать в определенное место»> прогон «плата ямщикам, возницам за провоз людей и грузов; сбор с населения за содержание ямской гоньбы», например: «взяти по окладу... ямщикомъ на прогоны» (1682) [28, вып. 20, с. 113]. Сбор с населения на содержание ямской гоньбы, а также плату ямщикам за доставку грузов называли прогонными деньгами: «а как те охотники на яме устроятся и имъ давати прогонныя денги по нашему указу» (1606) [28, вып. 20, с. 114], «А что де имъ доведется на Чердынцахъ взяти прогонныхъ денегъ за прошлые годы, по загоннымъ памятемъ, и они де имъ техъ денегъ не платят» (1621) [28, вып. 5, с. 171].

На станциях существовали ямские прогонные (загонные) книги, или книги регистрации и оплаты ямской гоньбы, в которых фиксировалось, в частности, количество прогонных (загонных) денег, выдаваемых ямщикам и почтовым гонцам за прогон. Примеры из текстов XVII в.: «А доправил язъ ему на Мурашкинскихъ и на Лысковскихъ старостахъ емскихъ денегъ, что оне загоняли, 22 рубля» (1615) [28, вып. 5, с. 172], «А что де имъ доведется на Чердынцахъ взяти прогонныхъ денегъ за прошлые годы, по загоннымъ памятемъ, и они де имъ техъ денегъ не платят» (1621) [28, вып. 5, с. 171], «довелось вязьмичем, посадским людем, платить... в Ямской приказ ямских денег по 196 рублев» (1648) [4, с. 194], «книги ямские загонные съ Турецкого яму на понизовую воду до Соли Вычегоцкой» (1679) [28, вып. 5, с.171]. 
Место проживания ямщиков называлось ямская слобода. Позднее это название сохранилось в наименованиях пригородных слобод во многих городах России [43, с. 664]. Примеры из текстов XVII в.: «охотникъ Матвейко Онисевъ сынъ, а живетъ туто-жъ въ ямской слободе» (1601) [28, вып. 13, c. 186], «и Ямъскеи слободы охотъники сказали во обыску...» (1618) [23, с. 106], «на оброк наперед сег никому не отдано ...ни к чрным волостям и къ ямским слободам» (1643) [24, с. 86], «под ямскою Акименскою слободою утонул» (1679) [21, с. 197], «И ты де прислалъ къ нимъ въ Ямскую слободу... человекъ с тритцать» (1699) [28, вып. 4, с. 77].

«Иногда при устройстве ямской слободы частные землевладельцы обязаны были уступать часть земли под ямские дворы и пашню» [42]. «Поощрялось приписывание к ямским слободам сирот, бобылей и всевозможных обедневших из-за Смуты людей, для которых поступление в ямщики было способом как-то выйти из крайней нужды» [14]. А.М. Кошкарева пишет, что в Сибири с начала XVII в. вместе с мерами по колонизации края принимались меры по увеличению ямщицких слобод и пополнению их русскими людьми. Устройство слобод с чисто русским населением на берегах Иртыша относится к 30-м гг. XVII столетия [18, с. 30]. Слободой называлось поселение или группа административно связанных между собой поселений, жители которых получали различные льготы и временно освобождались от уплаты налогов и повинностей [28, вып. 25].

Итак, прилагательное ямской являлось связующим звеном между существительными, обозначавшими деятелей (охотник, приказчик), места действия (приказ, слобода), денежные отношения (деньги, книги), средства транспорта (подвода, лошадь) и сами действия (гоньба). Благодаря относительной семантике прилагательного ямской имелась возможность объединения всех этих представлений в единый профессиональный концепт «Ямская гоньба».

Вполне возможно, что именно прилагательное ямской стало одним из источников образования самого слова ямщик. Об этом пишут, например, авторы коллективной монографии «Суффиксальное словообразование существительных в восточнославянских языках XV-XVII вв.», ссылаясь, в частности, на мнение Г. П. Павского: «Суффикс -щзик возник на восточнославянской почве не ранее XIII в. в результате морфологического переразложения основ существительных, образованных посредством

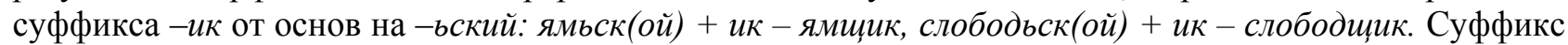
- щзик по своему происхождению связан с народно-разговорной языковой сферой» [32, с. 28].

Хотя чаще всего происхождение этого слова описывается как прямое заимствование из тюркского: «самые слова «ямъ» и «ямщикъ» - татарские; первое происходить от «дзямъ», дорога, второе от «ям-чи», проводник» [26, с. 800]; др.-русск. ямьщиикъ (грам. 1356 и др.) из тюрк. (ср. тур. јатс̌у «ямщик», чагат. јатс̌ - то же; сближено вторично с образованиями на -ик [35]; тюркск. ямчbl - «почтальон» в русск. яз. переоформилось под влиянием слов м. р. на -щик; в основе тюркск. ямчы (-чы суф. действующего лица)» [40].

Авторы статьи об образе ямщика в русской культуре А.П. Страшова и А.В. Параил, анализируя материалы словаря Срезневского, пришли к следующему выводу относительно первоначального значения слова ямщик и предшествовавшего ему слова ямник: в древнерусском языке словом ямникъ назывался тот, кто брал повинность с гонцов, а начальник над «ямниками» назывался ямщик; впоследствии и самих гонцов стали называть ямщฺиками [31]. По-видимому, этот вывод также близок к истине, поскольку в словаре И.И. Срезневского содержатся следующие сведения: ямьникъ - сборщик ямского сбора (пример 1402 г.), ямьщчикъ - заведующий ямскою повинностью (1356 г.), ямьщина ямская повинность, денежный сбор на ямскую гоньбу (1578 г.) [30].

Можно предположить, что в самом начале использования слова ямщик, сошлись два пути его появления - и заимствование, и наличие в русском языке соответствующей модели образования имен профессионального деятеля. Хотя всё же стоит обратить внимание и на то, что в материалах периода XVI-XVII вв. контекстуально сближенными являются взаимозаменяемые наименования ямской охотник и ямщиик. Синтагматическая связь данных единиц, как представляется, вполне может согласовываться с их парадигматическими отношениями (ямской охотник / ямщик) и с известной тенденцией в языке этого периода к свертыванию развернутых наименований действующих лиц (по типу сапожный мастер > сапожник).

В деловой письменности существительное ямщзик представлено, в основном, в следующих четырех ситуативных контекстах - «Сбор пошлины» и «Денежные отношения», «Место службы», «Лошадь ямщика», «Происшествия с ямщиками». 
В подгруппе «Сбор пошлины» слово ямщик встречается в одном ряду с наименованиями других лиц, причастных к сбору податей (факты XV - начала XVI в.). Так, в грамоте об освобождении от повинностей крестьян монастырского села, читаем: «в околицю въ его не въещають ни ямъщик ни боровщик ни бобровник» (1501) [22, с. 10], в другой льготной грамоте: «и я тем людем дан свои и ямъ отложил на три года... на два года не надобед ни дан ни ямъ а волостел мои въ его уездъ не вьезжает ни ямшик ни боровшик ни бобровник ни закосник ни бортник» (1427, сп. XVII в.) [22, с. 82].

Это наиболее архаичные контексты - ямщиком здесь назван сборщик пошлины для ямских станов, причем это слово входит в один ряд с боровщиком, бобровником, закосником, бортником, которые вполне определенно соотносились в языке того периода с названиями податей - боровое, бобровное, бортное, закосное. Так, закосникъ - это человек, следивший за исполнением повинности косить на кого-либо сено и взимавший закосную пошлину, или закосное, денежный побор, заменяющий один из видов натурального обложения (обязанность участвовать в закосе «сенокошении», косить на кого-либо сено) [28, вып. 5]. Такого же рода соотношения находим и для других представленных здесь наименований лиц. В связи с этим слово ямщик, как входящее в данный ряд, вполне могло быть мотивировано субстантивом ямское в значении «ямская пошлина».

Отражение ситуации «Денежные отношения» находим в текстах XVI в., в частности, в отписке о получении ямских денег - «взяли в государеву казну... ямских денег» $(1574)[5$, с. 49] и в льготной грамоте - «а в те им лготные лета государевых ямских и приметных денег не давати» (1577) [5, с. 93].

К ситуативной группе «Место службы» отнесем контексты с указанием города, где проживал или работал ямщик, например: «яз Нехорошои Карповъ снъ елеикои ямщик» (1620) [23, с. 143], «а продал таге свою кобылу курскому емщику Тимофею Юдину» (1624) [25, с. 117], «купил ... у емщика Твери города Стенки Щарапова мерин гнед» (1647) [25, с. 13], «Нижнего города емъщикъ Киприянъ Беляев явил конь калмыцкои» (1647) [25, с. 216], «мченскои емъщикъ Федор Уваров явил меринъ грива налева» (1647) [25, с. 223], «...бьетъ челомъ муромского яму ямщикъ Стенка Злобинъ» (1679) [21, с. 197]. Здесь встречаются указания на города Елец, Курск, Тверь, Нижний Новгород, Мценск, Муром. Известно, что с Москвой в XVII в. ямскими станами были соединены также Архангельск, Новгород, Псков, Смоленск и другие города [26, с. 800]. «Торговый путь из Вологды в Москву шел на Ярославль, Ростов, Переяславль; на этом пути устроено было 14 ямов» [33, с. 571].

Идентификация ямщика именно по месту службы отражает его официальный статус. Историк B.А. Оборин пишет о том, что в XVI в. часть ямщиков входила в особую социальную категорию служильх людей, которые получали денежное и натуральное жалование от государства. «Кроме несения службы часть из них занималась ремеслом и сельским хозяйством, вела торговлю с местным населением используя служебные командировки, что ставило их в более выгодное положение в конкуренции с посадскими людьми» [20, с. 145, 149].

Группа контекстов, связанных с «лошадью ямщика», - это сообщения о купле-продаже лошадей и их описание, например: «купил ... у емщика Твери города Стенки Щарапова мерин гнед грива направа с отметом восми лет» (1647) [25, с. 13], «Нижнего города емъщикъ Киприянъ Беляев явил конь калмыцкои шерстью гнед..., а продал белогороцкому козачему ездочному галове Василью Ребинину» (1647) [25, с. 216], «мченскои емъщикъ Федор Уваров явил меринъ грива налева... на левои бедре петно емъскоя» (1647) [25, с. 223]. Лошадей продавали и непосредственно на ямской станции. Так, В.И. Даль в рассказе «Хмель, сон и явь» (1843 г.) пишет: «...степную лошадку можно продать без убытку на каком-нибудь яму».

В приведенных выше фрагментах находим такие сочетания, как «купил мерин», «явил конь», «продал конь», «явил мерин» (мерин - холощеный жеребец). Имелись также некоторые специальные названия для лошадей, например, гонный мерин: «Ямской охотникъ Кондратко Яковлевъ, а у него 2 мерина гонныхъ: меринъ воронъ... да меринъ рыжъ» (1600) [28, вып. 9, с. 100].

O.Н. Катионов в работе «Московско-Сибирский тракт и его жители в XVII-XIX вв.» на материале произведений Д.Н. Мамина-Сибиряка проанализировал характеристику ямщиков через их отношение к лошадям: «Одни любили лошадей и относились к ним бережно, другие видели только в них способ передвижения, с их помощью они зарабатывали. По тем окрикам, которые Дмитрий Наркисович слышал от ямщиков в пути, можно сделать определенные выводы»: «Hy-ко, $6 b$, oмморошные, помешивай!..» («Мертвое озеро»). «...Егор Иваныч принялся ругать ни в чем не повинную расейсую пеганку, даже пригрозил ей кулаком и пообещал продать за три целковых Чибуртаю, который ее съест» («Клад Кучума»). Но иногда «...nроявлялись болезненные преувеличения достоинств гнед- 
$\kappa a »$ («Клад Кучума»). Все зависело от того, чьи были лошади, если собственные, то к ним и отношение бережливое [17].

Последняя группа из выделяемых ситуаций - «Происшествия с ямщиками». Известно, что ямской промысел был и тяжелым, и опасным. Приведем некоторые сообщения на эту тему: «ямской приказщик Федор Шевелев взял на ям сильно и на яму ево сажал в железа и вымучил на него запись житейскую, да кабалу в десяти рублях» (1639) [14], «и ямщики разбежались, а подводы наймовали дорогою ценою» (1644) [4, с. 95], «...бьеть челомъ муромского яму ямщикъ Стенка Злобинъ ...отцъ мои Овдокимъ Злобинъ под ямскою Акименскою слободою утонул...(1679) [21, с. 197], «техъ ямщиковъ 6 приказной избе держишь и мучишь въ иепи... и съ того де мученья берешь съ нихъ денежные взятки великие» (1699) [28. Вып. 10, с. 164], «И ты де прислалъ к нимъ въ Ямскую слободу... человекъ с тритцать и болши, и учали де безъ нихъ ямщиковъ за женами ихъ и за детми по улицамъ и по дворамъ ихъ гонять съ дубьемъ и с ножами и схватавъ бить и увечить» (1699) [19, с. 357]. Здесь отражены ситуации побега ямщиков со службы, издевательств над ними в приказных избах, денежных поборов и др.

Как в любой сфере профессионального труда, в среде ямщиков сложилась определенная языковая специфика. А.М. Кошкарева, автор «Очерков сибирской словесности», пришла к выводу, что лексика ямского промысла в XIX в. состояла из двух неравных по своему объему групп: слова, связанные с обозначением видов промысла и общим понятием «ямщичить», и слова, связанные с организацией и проведением ямщины [18]. Специальное слово ямщичить, пишет исследователь, в говоpax имело синоним проводничать, употребительное в Тобольской губернии в конце XIX в. Кроме того, зафиксированы словосочетания идти в извоз (в ямщину), ходить гужевой (в извоз, в ямщину), возить товар гужом и др. [18].

Интересный материал, касающийся как имен нарицательных, так имен собственных, сформировавшихся в данной профессиональной сфере, собран в труде историка А.Г. Мосина «Исторические корни уральских фамилий» [19]. Автор пишет: «Особую, чрезвычайно интересную и совершенно неизученную на сегодня группу населения Урала, по своему общественному положению скорее принадлежавшую к служилым, а по характеру ведения хозяйства стоявшую ближе к крестьянам, составляли ямщики. Ко времени составления переписи 1624 г. им принадлежали десятки дворов как в верхотурской Ямской слободе, так и в подгородной волости и по р. Тагилу, где со временем ими было основано множество деревень. Уже в этой переписи многие ямщики записаны с фамилиями или прозвищами, от которых позднее образовались фамилии их потомков: Якимко Харапугин, Михалко и Кирилко Енталцовы, Данилко Голомолзин, Нечайко Мухлынин, Первушка Махнев, Лева и Фетка Черепановы, Гаврилко Стрижков, Матюшка Рубцов, Мишка Закретня, Володка и Иван Комаровы, Семейка Чюраков, «Офонасей да Пятой да Девятой Степановы дети Ощепковы», Иван и Томилко Переваловы, Кузя Прянишников, Офоня Попко (или Попок), Сидор Чапурин, Лева и Семейка Брилины (Брылины), Юшка Колода, Фетка Телегин, Фетка Пятибратенников, Митка Кишкин, Ивашко Мухлыня, Федка Черепан, Ивашко, Петрушка и Ондрюшка Самковы, «Павлик да Томилка Васильевы дети Чертова», Васка Федоров сын Клест. На протяжении последующих четырех десятилетий какая-то часть этих ямщиков, их детей и внуков перешла в другие категории населения (служилые, посадские, крестьяне), но многие роды сохранялись именно как ямщицкие [19, с. 354].

Далее автор говорит о собственно «профессиональных» фамилиях ямщиков, то есть связанных своим происхождением с названиями каких-либо ситуаций в их жизни: «Что касается специфически ямщицких фамилий, семантика которых отражает какие-то стороны профессиональной деятельности ямщиков, то к их числу должна быть отнесена прежде всего фамилия Перевалов, получившая особенно широкое распространение на Урале. Возможно, сюда же следует отнести фамилию Закрятин известную у крестьян д. Чупиной ... с переписи 1710 г. Не исключено, что предком уральских Закрятиных был упоминавшийся выше ямщик Мишка Закретня» [19, с. 357].

В сносках А.Г. Мосин дает лексикографические ссылки на слова перевал и крятать. Перевал «перегон, упряжка, станция» (Даль), «расстояние между остановками, перегон, а также сама станция», «место, населенный пункт, где останавливались приезжие» (СРНГ) [19, с. 357]. Добавим, что в «Словаре русского языка XVI-XVII вв.» глагол перевалить приводится только в значении «перекинуть» (например, через колоду) и существительное перевалка - только о грузе [28, вып. 14]. Таким образом, слово перевал в указанных выше Мосиным значениях «перегон» и «станция», по-видимому, более позднего происхождения и связано с расширением семантики глагола перевалить до значения «перейти» и, в частности, «перейти (через горный хребет)» [34]. Одним из связующих звеньев в движении словообра- 
зовательной семантики могло быть сочетание перевалочный пункт. Отметим фамильное прозвище Перевалов, фиксируемое еще в тексте XVII в. - «усолец Савелий Перевалов» [3, с. 490], однако оно, являлось, скорее, отсылкой к трудовому процессу по переваливанию грузов, а не к ямской службе.

Значение глагола крятать Мосин дает по словарю под ред. В.И. Даля и словарю русских народных говоров: «сдвигать с места, перемещать, двигать; трогать с места (о лошади, повозке и т.п.)», «нагружать, накладывать поклажу», крятаться - «трогаться, двигаться с места; уезжать, уходить», ср. также кретать - «трогать, двигать, сдвигать, столкнуть с места, подать взад либо вперед» [19, с. 357].

Безусловно, что ряд лексики, используемой в языке ямщиков, можно было бы продолжить. Например, В.В. Виноградов в «Очерках по истории русского литературного языка» пишет о том, что слово колея в XVIII в. чаще других употреблялось именно ямщиками и означало «прорез от колес по густой грязи» [9, с. 331]. Устойчивые сочетания «избитая колея», «своя колея» вошли в общерусский языковой фонд. Отметим и достаточно известную в наши дни фамилию Ямщиков. Примеры из исторических текстов: дозорщик Иван Ямщиков [3, с. 201], купцы Ямщиковы (XVIII в.) [2].

Итак, ямской промысел отражен в памятниках русской письменности XVII в., прежде всего, однокоренным рядом слов: ям, ямской, ямщик, ямщина. Прилагательное ямской через сочетаемость объединило в синтагматике и парадигматике существительные приказ, приказчик, охотник, подвода, ломадь, гоньба, слобода, книги, деньги и некоторые другие. Процессуальная семантика выражена глаголами и глагольными сочетаниями гнать, ездить, стоять на яму, ямщичить, сбежать, жить в бегах, жить в ямской слободе, продать / купить / явить (лошадь) и т.п. Существую две основные версии происхождения слова ямщик: ямьск(ой) + ик > ямщик; тюрк. ямчи «проводник» > ямщик (под влиянием слов на -щик).

Другое наименование деятеля, связанного со сферой перевозок на лошадях, - это существительное извозчик. Для носителя современного русского языка образы, стоящие за словами ямщик и извозчик, - разные. Ямщик в национальном сознании связан с тройкой лошадей, дальней дорогой и, конечно, с пушкинским - «Что-то слышится родное в долгих песнях ямщика». А извозчик представляется в образе кучера на городских улицах, где ездят кареты и горят фонари. Современные дети, как правило, вообще не знают этих слов. На вопрос, «Что означают слова ямщик и извозчик?», восьмилетний мальчик ответил: «Не знаю», девочка двенадцати лет высказала предположение: «Ямщик кто роет яму? Извозчик - ...возит?».

Внутренняя форма слова извозчик действительно до сих пор остается достаточно ясной, и кажется, что восстановление предшествующей ему словообразовательной цепочки не представляет особого труда. Но уже с определением ближайшего звена возникает проблема: если это существительное отглагольное, то от какого глагола оно образовано? Было ли слово изво́зить?

В «Этимологическом словаре славянских языков» под ред. О.Н. Трубачева находим этот глагол: jbzvoziti, др.-русск. извозити «перевозить, возить» (1641г.). Здесь же дается ссылка на словарь И.И. Срезневского: извозитися «переправляться через реку» (1281г.). Образование глагола определяется как сложение *jbz и * voziti [41, вып. 9, с. 101]. В «Словаре русского языка XI-XVII вв.» также указан глагол извозити в значениях «перевозить, возить» и «переправляться через реку»; приведена цитата начала XVII в.: «...лето и зиму хлебъ извозили» (1614) [28, вып. 6]. В этимологическом словаре под ред. Н.М. Шанского глагол извозить поясняется как «многократный к везти» [40].

Если слово извозчик действительно формировалось как название лица по действию, то схема его образования была такой: извозити > извозьщикъ (извощик, извозчик).

Однако в монографии «Древнерусское именное словообразование» Ж.Ж. Варбот пишет о том, что бо́льшая часть древнерусских имен на -ьчикъ, -ьщик, соотносительных с глаголами, образована, вероятно, от соответствующих корневых отглагольных имен: ср. отъводьчик «межевщик» - отъводъ «граница», доводьщикъ «должностное лицо» - доводъ «разыскание», заезщикъъ «сборщик заезда (подати)» - заездъ «пошлина», прикащикъ «управитель» - приказъ, закладьщик - закладъ, опищикъ «составитель описи» - опись, поклепьщикъ «клеветник»- поклепъ «клевета» и др. «Представляется, однако, возможным, - пишет автор, - и непосредственное отглагольное образование: ср. отсутствие корневых имен в соответствии с выледьщикъ (к выввести), письчикъ (к писати) [8, с. 92].

Таким образом, у слова извозчик могла быть двойная мотивированность - глаголом извозить и существительным извоз, хотя более убедительной, на наш взгляд, является схема «извозити > извозъ $>$ извозьщикъ», как имеющая много примеров образования таких форм в древнерусском словообразовании. Кроме того, отметим крайне редкую фиксацию глагола извозити в письменности XVI-XVII 
вв. и наличием устойчивого сочетания кормиться извозом, например: «Кормился извозомъ и былъ в найму въ подводахъ» (XVII в.) [28, вып. 6]. Схема «кормиться чем» представлена как ключевая практически для любого крестьянского промысла, она отражала вид занятия, например: «корлился работою своею делал портное дело» (1676) [28, вып. 7, с. 322]. Модель: кормился чем - извозом, значит был извозчиком. Отметим также сочетанием быть в извозе: «Темъ извощикомъ из судовъ на гостинъ дворъ всякие товары велеть возить, а мимо ихъ никому в извозе не быти» (1617) [28, вып. 6, с. 130]. Быть извозчиком означало «идти в извоз», «быть в извозе», «кормиться извозом». Для материалов XVI-XVII вв. такая соотнесенность очевидна.

Ю.С. Азарх в монографии «Словообразование и формообразование существительных в истории русского языка» также пишет об отсубстантивном наименовании лиц мужского пола на изикъ/чикъ; эти существительные имеют мутационное словообразовательное значение носителя предметного признака; слова на -щъикъ/чикъ именуют лицо по должности [1, с. 88]. В коллективной монографии «Суффиксальное словообразование существительных в восточнославянских языках XVXVII вв.» (отв. ред. В.И. Борковский) утверждается, что «суффикс -щзик (вариант -чик) сочетается с основами существительных с начала своего функционирования в русском языке - c XIII-XIV вв. B старорусском языке имеются образования с суфф. -щзик от основ существительных со значением конкретного предмета и существительных с отвлеченным значением» [32, с. 44]. Примеры слов первого типа - каменщик, кирпищик, второго - приказщчик, помещчик и др.

Существительное извоз и прилагательное извозный использовались в контекстах с описанием перевозки грузов не только на лошадях, но и по воде, например: «на извозномъ карбасе» (1695) [28, вып. 6, с. 127] (сравним со значениями слов перевоз и перевозчик, также связанными с переправой через реку). Еще интересный пример, в котором нашло отражение именование извощиками лодочников: «да наняли деи вашихъ извощиковъ бусниковъ... под свой товар да и поехали дей с Колыване» (XVI в.) [28, вып. 10, с. 224], здесь бусник от буса «лодка», «выдолбленное судно).

$\mathrm{B}$ «Этимологическом словаре славянских языков. Праславянский лексический фонд» отмечено отглагольное существительное jbzvozъ - цслав. извозъ; болг. и́звос «подъем дороги в гору»; макед. и сербохорв. извоз «вывоз»; др.-русск. извозъ «перевозка товарных грузов на лошадях или по воде; извоз как промысел» (1592 г.), «перевоз, переправа (через реку) (1619 г.), русск. диал. извоз «обоз», «перевозка груза лошадьми», «спуск/подъем в гору» и др. Производное от глагола јьzvezti; cp. также jьzvoziti [41, вып. 9, с. 101].

Прилагательное извозный «относящийся к извозу, предназначенный для перевозки грузов» («извозный двор», «извозная снасть») еще в древнерусский период явилось производным для названия лица - извозьникъ «возчик» (в словаре Срезневского есть цитата из текста ХІ в.). От него было образовано прилагательное - извозницкий («извозницкая снасть») и глагол извозничати «заниматься перевозкой груза (товара) и людей на лошадях как постоянным или временным промыслом» [28, вып. 6]. Наименование лица извозчик (извозщчикъ) исторически заменило слово извозник, подобно смене наименований в паре ямник / ямщзик.

У существительного извозчик в текстах XVI-XVII вв. отмечаются следующие значения: «тот, кто занимается перевозкой грузов (товаров), вывозкой грузов от мест переправы», «тот, кто перевозит людей», в словаре указано также значение «лодочник» в описании Венеции [28, вып. 6]. Слово извозчик использовалось и как идентифицирующее при составлении списков людей, например: «На всполье во дворе Оноша Ивановъ извощикъ» (1544) [28, вып. 6, с. 130], «Во дворе Сидорко Симонов сын Оксентьев, извощик» (1646) [4, с. 173]. Закономерным является дальнейшее появление на этой основе имени собственного: «Трофим да Парша Степановы дети Извозчиковы» (1645) [4, с. 120].

В деловых памятниках русской письменности существительное извозчик представлено в контекстах, схожих со словом ямщзик - «Денежные отношения», «Место службы», «Лошадь извозчика» и некоторые другие. Однако событийное наполнение этих сфер заметно различается.

Ситуация «Денежные отношения» в текстах XVI-XVII вв. отражена, в основном, в сообщениях об оплате извозчикам за перевозку, например: «Платиль извощчикомъ, которые отвезли в Слободцкой перепищика», «И они давали извощикомъ найму на телегу на месецъ по три рубли» (1595) [28, вып. 6, с. 130], «извощиком Лаврентью Дворяшину да Василю Трифанову на три лошади дано извозу два рубли шесть алтнъ четыре днги» (1671) [21, с. 101]. Отличие от «ямщицкого» контекста состоит в том, что извозчики получают деньги за наем у них подводы («найму на телегу», «дано извозу»), за выполненную работу («платил извощикомъ»), тогда как в ямской сфере речь идет обычно о более 
отвлеченных операциях - «государевы ямские деньги» идут в казну или их (не)выдают из казны. Конечно, и извозчики платили пошлину, например, отворотную, взимавшуюся с извозчика, если он, не доезжая до условленного места, поворачивал обратно [28, вып. 13, с. 208].

В описаниях извозного промысла используется понятие «наём», например: «Нанять под ызвоз 12 лошадеи у посадцких людеи» (1592) [28, вып. 6], «Кормился извозомъ и быль в найму въ подводахъ у разбойников» (XVII в.) [28, вып. 6], «подводы наймовали дорогою ценой» [4, с. 105]. Как и слово гоньба, слово наём (найм) < наим < наимати (наймати) - это отглагольное существительное, обозначающее способ заработка. Но в отличие от слова гоньба, специализировавшегося в ямской сфере, слово наём использовалось очень широко, обозначая любую работу такого типа. В текстах XVII в. встречаем слова наемный, наймит, наймовать, например: «работные наемные люди», «наймитов, которые живуть у тотаръ в наймехъ», «работных людей ...велено наймовать» [28, вып. 10, c. 101-105]. Н.А. Бакланова говорит о том, что в XVII в. для извоза нередко привлекались наемные извозчики из числа беднейших посадских людей, которые зачастую делали этот промысел своей постоянной профессией [6, с. 161].

Условно «местом службы» извозчика, как наемного работника может быть назван Земский приказ: «...ведать извощиковъ всякихъ людей въ Земскомъ приказе и велель ихъ переписать» [28, вып. 6, с. 130]. У ямщиков, как говорилось выше, это их связь с конкретной ямской станцией. Если местом проживания ямщиков были ямские слободы, то и извозчики также нередко жили в извощичьих слободаx, например: «Афанасью въ пушкарской... и въ извошичьей слободахъ, ездить въ объезде для береженья оть огня» (1696) [28, вып. 6, с. 130]. Существовали также и дворы извозные как «место пристанища едущих с грузом, товаром»: «и дворы извозные извощикомъ учинити» (1617) [28, вып. 6, с. 127].

«Лошадь извозчика», как средство передвижения, была основной его заботой, как и для ямщика. В тексте конца XVI в. встречаем описание гибели извозчичьих лошадей как большой беды, «нужды»: «Любо которые извощики въ дороге лошадми опадутъ или какая иная нужа будетъ» (1595) [28, вып. 13 с. 10], «Подводы съ надсады, и съ безкормицы, и съ волокиты многия померли» (1622) [28, вып. 16, с. 236]. В последнем примере в сочетании «подводы померли» метонимически сообщается о смерти лошадей, для извозчика подвода - это именно лошадь с телегой (санями). Подводы так и назывались - извошиковы или извощичьи: «Выгруживали суды посольские и наклали, государь, на извощиковы подводы, на девять телегь рухляди посольской» (1600) [28, вып. 10 с. 118$]$, «извощичьи подводы» (1674) [28, вып. 6, с. 130].

Разница между фрагментами о лошадях «извощиковых» и ямщицких заключается, прежде всего, в том, что в сообщениях об извозном промысле на первом месте стоит забота о рабочем состоянии лошадей: беда, если извозчики «лошадьми опадут». В ямской сфере о лошадях говорится в основном в связи с их куплей-продажей и при необходимости описать коня для его опознавания. Эта разница, на наш взгляд, объясняется тем, что извозчик, как нанятый возница, либо использует для извоза своих лошадей, либо ездит на наемных, например: «Нанять под ызвоз 12 лошадеи у посадцких людеи» (1592) [28, вып. 6], и тех и других он должен беречь. В ситуациях же купли-продажи лошадей он именуется просто крестьянином, в результате чего оказывается скрытым то, что это именно извозчик.

Историк Н. А. Бакланова пишет о том, что в XVII в. подводы, нагруженные рыбой, а также солью, икрой и другими товарами, отправлялись целыми обозами, и наибольшее количество обозов отправлялось в декабре - январе, когда устанавливался санный путь, так как зимний путь был легче летнего [6, с. 163-165]. Приведем пример из текста начала века: «Извощики поехали изъ Кайгородка на Верхотурие... с сибирскими хлебными запасы» (1605) [28. Вып. 5, с. 259].

Помимо торгового извоза, существовал частный извоз - перевозка частными владельцами пассажиров и грузов; им занимались прежде всего крестьяне [15, с. 97]. Судя по памятникам письменности, в XVII в. частные извозчики перевозили самые разнообразные грузы: «пивнога запасу что возили на мелницу и с мелници» (1616) [25, с. 70], «привезено на винокурню на горны глины тритцать возовъ извощиком дано тритцать алтнъ», «погреб льду навозили извощикомъ», «Да на яръманку же ездили... c питьемъ извощикомъ села Шугори» (1671) [21, с. 95, 100, 101] и др. Перевозили также и людей. Выше был дан пример с «перепищиком», приведем еще один фрагмент: «ездили кружечного двора целовалники Сергей да Семен да Естифей великого гсдря с наличною с уплатною казною от Ростова до Москвы извощиком Лаврентью Дворяшину да Василю Трифанову на три лошади дано извозу два рубли шесть алтнъ четыре днги» (1671) [21, с. 101]. 
Н.Б. Голикова отмечает, что, например, в Ярославле в начале XVIII в. «извозчики составляли третью по численности группу наемных работников. ...Нанимались извозчики большей частью целыми партиями по 20-30 и более подвод, ручаясь друг за друга круговой порукой» $[11$, с. 86]. В XIX в. извоз также имел большое значение в занятиях русских крестьян. «Географическое положение Среднего Поволжья на пути из центральных районов на Урал и Сибирь, наличие хорошего санного пути по Волге, Каме и другим крупным рекам способствовало развитию здесь сухопутного транспорта», «по зимним дорогам Среднего Поволжья вереницей шли возы, груженые рыбой, пушниной, салом и др. товарами» - пишет Е.П. Бусыгин в монографии «Русское сельское население Среднего Поволжья» [7, с. 175, 385].

До сих пор в русском языке перевозка на лошадях, в отличие от других видов перевозок, называется гужевым транспортом. Это прилагательное использовалось уже и в XVII в., например, в составе наименования товара, привезенного сухим путем, на повозках: «гужевых оброчных дров» (1662) [28, вып. 4, с. 155]. Прилагательное гужевой было образовано от существительного гужъ, так назывались толстые веревки или ремни, которыми стягивали груз на повозке. Наречие гужсм «гуськом, вереницей; толпой» отсылает к тому времени, когда по дорогам России двигались груженые товарами обозы. Исторические материалы отразили и старинное значение слова гуж - «петля из ремня или веревки у хомута, в которую вставляется при запряжке конец оглобли и дуги» [29]. Пословица «Взявшись за гуж, не говори, что не дюж» также хранит информацию об этом слове. Существовало бранное прозвище извозчика или кучера - гужеед [39, с. 6], в современном городском просторечии известен глагол диалектного происхождения гужевать в значении «гулять, веселиться» [27, вып. 7].

Во второй половине XVII в. гужевыми назывались сами извозчики, доставлявшие товары по дорогам, в отличие от судовых, перевозивших товары по рекам [6, с. 131]. Доставка грузов в Москву из Астрахани производилась в два приема: сначала по воде, затем, когда случался «замороз» и судно не успевало дойти до Нижнего Новгорода, нанимались извозчики. «Если водный транспорт обслуживался преимущественно посадскими людьми, то гужевой - главным образом крестьянами. Посадские люди в зимнее время, по окончании навигации, возвращались к своим обычным занятиям - ремеслу и торговле. Крестьяне, закончив полевые работы, зимой могли заниматься извозом» [6, с. 162]. На территории Удмуртии основным средством передвижения, доступным для крестьянства, еще и во второй половине XIX в. также был гужевой [16, с. 374].

В литературе сообщается об особом жаргоне извозчиков, существовавшем в XIX в. Даются ссылки на слова канать «отправляться выполнять заказ, выигранный по жребию», биржа - Лубянская площадь, где за символическую плату можно было напоить лошадь из фонтана, хабарить «штрафовать». Тогда возникло и устойчивое выражение «ругается как извозчик».

За изменениями в социально-экономической жизни страны неизбежно следуют изменения и в содержании языковых знаков. Сравнивая слово извозчик с историей слова ямщик, можно отметить, что, имея совпадающие смысловые компоненты, семантически они развивались в противоположных направлениях. Существительное ямщик постепенно, на протяжении многих веков, расширяло поле своего применения вслед за изменениями функций этой категории людей: «сборщик ямного» > «нанимаемый для этой службы», «прикрепленный службой к яму» > «перевозчик курьеров и почты на лошадях» > «перевозчик людей на лошадях». У существительного извозчик, напротив, произошла конкретизация значения: «тот, кто занимается перевозкой грузов на лошадях и по воде» > «тот, кто перевозит людей / грузы на лошадях» > «городской извозчик».

Эта разница была обусловлена, на наш взгляд, и внутриязыковыми причинами, а именно категориальной принадлежностью исходных слов. Ям «стан» - это пространственная номинация, а слово извоз обозначало передвижение в пространстве. Слова ямщик и извозчик, соотнесенные с этими номинациями, изначально расходились в концептуальных представлениях об этих деятелях: ямщик тот, кто передвигается по земной поверхности, дороге, извозчик - тот, кто возит вообще, и по земле, и по воде.

В деловых текстах XVII в. встречаются отдельные случаи синтагматического сближения лексем из этих разных лексико-семантических групп, например: «Муромскимъ ямщикомъ межъ своихъ делъ в Муроме извозничати, у гостей соль и медъ, и рыбу, и всякий товаръ возити» (1640) [28, вып. 6 , с.126]. Здесь хорошо заметна разница понятий, связанных с обозначениями ямщицкой и извозчичьей сфер деятельности: «товаръ возити» - дело извозчиков, а не ямщиков. Сравним также в одном из рассказов В.И. Даля (1847): «Нижегородские татары... киргизских и калмыцких лошадей... перепродают по дороге с барышом извозчикам и ямщчикам». 
Итак, извозчик «возил товары (грузы)», «нанимался в извоз», «находился в извозе», то есть занимался «извозным промыслом», «возил», «отвозил», «ездил», в общем - «извозничал». А ямщик «стоял на яму», «гоньбу гонял» - «ямщичал».

Извозный промысел отражен в памятниках русской письменности XVI-XVII вв., прежде всего, однокоренным рядом слов: извозити, извоз, извозный, извозник, извозницкий, извозчик, извозчиков, извозщичий. Прилагательные через сочетаемость с существительными объединяют в синтагматике и парадигматике существительные подвода (извощикова, извощзичья), слобода (извощиччья), двор (извозный), снасть (извозная, извозницкая), промысел (извозный) и некоторые другие. Процессуальная семантика выражалается глаголами и устойчивыми глагольными сочетаниями ездить, (om)возить, uзвозничать, идти в извоз, кормиться извозом и некоторыми другими.

Версии происхождения слова извозчик две: извозити > извозьщзикъ (извощик, извозчик); извозити $>$ извозъ > извозьщчикъ. Слово извозчик сменило предшествовавшее ему исторически слово извозник, а в XVI-XVII вв. контекстуально сближенным с ним было слово подводчик «сдававший в наем подводы».

Итак, в содержательном плане лексика ямского и извозного промыслов имела немало общего, поскольку основным занятием являлась перевозка на лошадях. В обеих профессиональных сферах использовались названия самих возчиков, транспортных средств, способов передвижения, видов перевозимых объектов. История закрепления слов ямщик и извозчик в русском языке отражает универ-

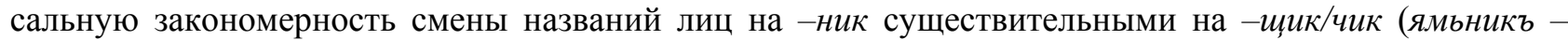
ямьщиикъ, извозьникъ-извозьщуикъ).

Однако словообразовательные истории этих двух слов различаются: слово ямщик через звенья ямчи и ямской восходит к заимствованию с пространственным значением ямъ «станция на дороге»; а у слова извозчик в начале его словообразовательного ряда находился глагол изво́зити, обозначавший передвижение в пространстве, и отглагольное имя извоз.

В памятниках деловой письменности XVI-XVII вв. оба промысла представлены, прежде всего, двумя рядами однокоренных групп лексики: ям, ямской, ямщчик, ямщчна; извозити, извоз, извозный, извозчик. Прилагательные ямской и извозный (извощзичий, извощзиков) в данных текстах через сочетаемость объединяют существительные (ямской) приказ, приказчик, охотник, подвода, лошадь, гоньба, слобода, книги, деньги; (извозный) двор, снасть, промысел, (извощчикова, извощичья) подвода, слобода и др. Общая единица здесь - подвода; добавим также слова лошадь и слобода, которые также отражены при описании обоих промыслов.

Процессуальная семантика выражается разными глагольными наименованиями, в ямской сфере - гнать, ездить, стоять на яму, ямщичить, сбежать, жить в бегах, жить в ямской слободе, продать / купить / явить (лочадь), в извозном промысле - словами ездить, (от)возить, извозничать, идти в извоз, кормиться извозом, быть в найму, наймовать. Только один глагол ездить, как имеющий наиболее широкое значение, фиксируется в обеих сферах. Таким образом, эти два, разных по своему историческому формированию крестьянских промысла, в языковом плане расходились своими ключевыми терминами, однако имели некоторые пересечения в использовании остальной лексики в связи с описанием схожих ситуаций перевозок на лошадях.

В коммуникативных сферах данных промыслов сложились специфические общие названия профессиональных занятий - гоньба и извоз. Эти слова имели ясную внутреннюю форму: первое было мотивировано глаголом гоняти «очень быстро ездить» (при перевозке гонцов и почты, прежде всего), второе - глаголом извозити «вывозить, возить» (грузы, товары). Гоньба и извоз являлись, по сути дела, именами соответствующих концептуальных областей, так как своим содержанием охватывали всё, что относилось к ямским перевозкам и извозному промыслу.

\section{СПИСОК ИСТОЧНИКОВ И ЛИТЕРАТУРЫ}

1. Азарх Ю.С. Словообразование и формообразование существительных в истории русского языка. М.: Наука, 1984.

2. Аксенов А.И. Генеалогия московского купечества XVIII в. Из истории формирования русской буржуазии. М.: Наука, 1988.

3. Акты писцового дела. Т. 2, вып. 1. М., 1917.

4. Акты писцового дела (1644-1661 гг.). М.: Наука, 1977. 
5. Акты социально-экономической истории севера России конца XV-XVI в. Акты Соловецкого монастыря. 1572-1584 гг. Л.: Наука, 1990.

6. Бакланова Н.А. Торгово-промышленная деятельность Калмыковых во второй половине XVII в. К истории формирования русской буржуазии. М.: Изд-во АН СССР, 1959.

7. Бусыгин Е.П. Русское сельское население Среднего Поволжья: историко-этнографическое исследование материальной культуры (середина XIX-нач. XX вв.). Казань: КазГУ, 1966.

8. Варбот Ж.Ж. Древнерусское именное словообразование. М.: Наука, 1969.

9. Виноградов В.В. Очерки по истории русского литературного языка XVII-XIX веков. М.: Высшая школа, 1982.

10. Гладилина Г.Л. Лексика лесного сплава в аспекте исторического терминоведения русского языка: автореф. дис. ... канд. филол. наук. Томск, 2005.

11. Голикова Н.Б. Наемный труд в городах Поволжья в первой четверти XVIII века. М., 1965.

12. Даль В.И. Толковый словарь живого великорусского языка. М., 1991-1993. Т. 1-4.

13. Елисеева Е.П. История лексики почтовой связи в русском языке: автореф. дис. ... канд. филол. наук. М., 1994.

14. Иванов П. Синий зипун, красный кушак: ямская гоньба от монголов до железных дорог // Родина: Российский исторический иллюстрированный журнал. 2001. № 12. С. 54-60.

15. История и культура Вятского края. М.: Академический Проект: Константа, 2005.

16. История Удмуртии: Конец XV - начало XX века / под ред. К.И. Куликова. Ижевск: УИИЯЛ РАН, 2004.

17. Катионов О.Н. Московско-Сибирский тракт и его жители в XVII-XIX вв. Новосибирск, 2004.

18. Кошкарева А.М. Очерки сибирской словесности. Учеб. пос. Нижневартовск: Изд-во Нижневартовского гуманитарного университета, 2010.

19. Мосин А.Г. Исторические корни уральских фамилий. Екатеринбург, 2008.

20. Оборин В.А. Заселение и освоение Урала в конце XI - начале XVII века. Иркутск: Изд-во Иркут. ун-та, 1990.

21. Памятники деловой письменности XVII в. Владимирский край / под ред. С.И. Коткова. М.: Наука, 1984.

22. Памятники русской письменности XV-XVI вв. Рязанский край / под ред. С.И. Коткова. М.: Наука, 1978.

23. Памятники южновеликорусского наречия. Конец XVI - начало XVII в. / под ред. С.И. Коткова. М.: Наука, 1990.

24. Памятники южновеликорусского наречия. Отказные книги / под ред. С.И. Коткова. М.: Наука, 1977.

25. Памятники южновеликорусского наречия. Таможенные книги / под ред. С.И. Коткова. М.: Наука, 1982.

26. Почта // Энциклопедический словарь. Издатели Ф.А. Брокгауз, И.А. Ефрон. СПб., 1898. Т. 48. С. $792-819$.

27. Словарь русских народных говоров. Вып. 1-49. М.; СПб.: 1965-2016.

28. Словарь русского языка XI - XVII вв. Вып. 1-30. М., СПб., 1975-2015.

29. Словарь русского языка XVIII в. Вып. 1-22. Л., СПб., 1984-2019.

30. Срезневский И.И. Материалы для словаря древнерусского языка по письменным памятникам. СПб, 1893.

31. Страшова А.П., Параил А.В. Коннотации образа ямщика в русской культуре // Верхневолжский филологический вестник. 2018. № 2.

32. Суффиксальное словообразование существительных в восточнославянских языках XV-XVII вв. M.: Наука, 1974.

33. Торговля // Энциклопедический словарь. Издатели Ф.А. Брокгауз, И.А. Ефрон. СПб., 1901. Т. 66. С. $541-587$.

34. Ушаков Д.Н. Толковый словарь русского языка: В 4 т. М., 1935-1940.

35. Фасмер М. Этимологический словарь русского языка. В 4 т. М.: Астрель, 2009.

36. Хитрова В.И. Дополнения к «Словарю русского языка XI-XVII вв.»// Проблемы развития языка. Саратов: Саратовский университет, 1981. С. 137-140.

37. Черных П.Я. Очерк русской исторической лексикологии. Древнерусский период. М.: Изд-во Московского университета, 1956.

38. Черных П.Я. Историко-этимологический словарь современного русского языка: 13560 слов. Т. 1-2. М.: Рус. яз., 1994.

39. Чичагов В.К. Из истории русских имен, отчеств и фамилий. М., 1959.

40. Шанский Н.М., Иванов В.В., Шанская Т.В. Краткий этимологический словарь русского языка. М.: Просвещение, 1975.

41. Этимологический словарь славянских языков. Праславянский лексический фонд / под ред. О.Н. Трубачева, А.Ф. Журавлева. Вып. 1-41. М.: Наука, 1974-2018.

42. Ямская повинность // Энциклопедический словарь. Издатели Ф.А. Брокгауз, И.А. Ефрон. СПб., 1904. Т. 82. С. 664.

43. Ямская слобода // Энциклопедический словарь. Издатели Ф.А. Брокгауз, И.А. Ефрон. СПб., 1904. Т. 82. С. 664. 
Шейдаева Светлана Григорьевна, доктор филологич наук, профессор

ФГБОУ ВО «Удмуртский государственный университет»

426034, Россия, г. Ижевск, ул. Университетская, 1 (корп. 2)

E-mail: Sheidaeva@mail.ru

\title{
S.G. Sheidayeva \\ VOCABULARY OF YAMSKOY [COACHMAN's] AND IZVOZNY [CABMAN's] CARRIER'S TRADE: HISTORICO-DERIVIATIONAL ASPECT
}

\author{
DOI: $10.35634 / 2412-9534-2021-31-6-1127-1142$
}

Based on the material from the Russian commercial written records of the XVI-XVII centuries, this article examines semantic and derivational features of the vocabulary of the yamskoy [coachman's] and izvoznyi [cabman's] carrier's trade. In terms of content, the words of these two professional spheres have much in common since the main occupation of yamshchiki [coachmen] and izvozchiki [cabmen] was transportation of people or goods by horse; here are used the names of characters, vehicles, travel modes, types of transported objects. The history of fixing of the words yamshchik [coachman] and izvozchik [cabman] in the Russian language reflects the universal pattern of changing the names of persons ending in -nik by the nouns ending in -shchik/chik (yamnik - yamshchik [coachman], izvoznik - izvozchik [cab$\operatorname{man}])$. At the same time, the categorical difference in the original names that were at the beginning of the wordformation chains caused a difference in the semantic development of the names of doers: in one case, this is a spatial nomination of yama [Russian word for a "pit'] denoting a "station on the road" (> yamchi, yamskoy > yamshchik [coachman]); in another one it is a designation of a movement in space izvoziti [Russian obsolete word for 'to carry'] ( $>$ izvoz > izvozchik [cabman]). In this regard, the names of persons right from the beginning differed in their conceptual representations of the doers: yamshchik [coachman] is the one who moves along the road, and izvozchik [cabman] is the one who "carries" something both on land and on water (like a carrier). Different communicative spheres of yamskoy [coachman's] (gonny [riding fast]) and izvozny [cabman's] carrier's trade gave birth to specific names of transportation: gon'ba [fast ride] and izvoz [carriage], which had clear internal forms: the first one was motivated by the verb gonyati [Russian obsolete word for "to ride fast", and the second one - by the verb izvoziti [Russian obsolete word for 'to carry outwards'] (cargo, goods).

Keywords: history of the Russian language, vocabulary of yamskoy [coachman's] and izvozny [cabman's] carrier's trade.

\section{REFERENCES}

1. Azarkh Yu.S. Slovoobrazovaniye i formoobrazovaniye sushchestvitelnykh v istorii russkogo yazyka [Word and Form Formation of Nouns in the History of the Russian Language]. Moscow: Nauka Publ., 1984. (In Russian).

2. Aksenov A.I. Genealogiya moskovskogo kupechestva XVIII v. Iz istorii formirovaniya russkoy burzhuazii [Genealogy of Moscow Merchantry of the XVIII Century. Excerpts on the History of the Russian Bourgeoisie Formation]. Moscow: Nauka Publ., 1988. (In Russian).

3. Akty pistsovogo dela [Acts of Cadasters). Vol. 2, no. 1. Moscow, 1917. (In Russian).

4. Akty pistsovogo dela 1644-1661 gg. [Acts of Cadasters 1644-1661 yrs.). Moscow: Nauka Publ., 1977. (In Russian).

5. Akty sotsialno-ekonomicheskoy istorii severa Rossii kontsa XV-XVI vekov. Akty Solovetskogo monastyrya. $1572-$ 1584 gody [Acts of Socio-Economic History of the North of Russia at the End of the XV-XVI Centuries. Acts of the Solovetsky Monastery. 1572-1584 yrs.]. Leningrad: Nauka Publ., 1990. (In Russian).

6. Baklanova N.A. Torgovo-promyshlennaya deyatelnost' Kalmykovykh vo vtoroy polovine 17 v. K istorii formirovaniya russkoy burzhuazii [The Kalmykovs' industrial and commercial activity in the second half of the 17th century. Background for the Russian bourgeoisie generation]. Moscow: Academy of Sciences of the USSR Publ., 1959. (In Russian).

7. Busygin E.P. Russkoye selskoye naseleniye Srednego Povolzhiya: istoriko-etnograficheskoye issledovaniye materialnoy kultury (seredina 19-nach. 20 vv.) [Russian rural population of the Middle Volga region: historical and ethnographic study of the material culture (the middle of the $19^{\text {th }}-$ the early 20th centuries]. Kazan, Kazan University Publ., 1966. (In Russian).

8. Varbot Zh.Zh. Drevnerusskoye imennoye slovoobrazovaniye [Old Russian Nominal Word Formation]. Moscow: Nauka Publ., 1969. (In Russian).

9. Vinogradov V.V. Ocherki po istorii russkogo literaturnogo yazyka XVII - XIX vekov [Essays on the History of the Russian Literary Language of the $17^{\text {th }}-19^{\text {th }}$ centuries]. Moscow: Vysshaya shkola Publ., 1982. (In Russian). 
10. Gladilina G.L. Leksika lesnogo splava v aspekte istoricheskogo terminovedeniya russkogo yazyka: dis. ... kand. filol. nauk [Vocabulary of Timber Floating in the Aspect of Historical Terminology Studies of the Russian Language. Thesis]. Tomsk, 2005. (In Russian).

11. Golikova N.B. Nayomnyi trud v gorodakh Povolzhjya v pervoy chetverty XVIII veka [Wage Labor in the Cities of the Volga Region in the First Quarter of the XVIII Century]. Moscow: Moscow University Publ., 1965. (In Russian).

12. Dal' V.I. Tolkovyi Slovar' zhivogo velikorusskogo yazyka [Explanatory Dictionary of the Living Great Russian Language]. Moscow, 1991-1993. Vol. 1-4. (In Russian).

13. Eliseeva E.P. Istoriya leksiki pochtovoy svyazi v russkom yazyke: avtoref. dis. ... kand. filol. nauk [History of vocabulary of the postal service in the Russian language. Abstract of thesis]. Moscow, 1994. (In Russian).

14. Ivanov P. Siniy zipun, krasny kushak: yamskaya gon'ba ot mongolov do zheleznykh dorog [Blue homespun coat, red waist belt: coachman's fast ride from the Mongols to the railways]. Rodina: Rossiyskiy istorichesky illyustrirovanny zhurnal [Motherland: Russian Historical Pictorial Magazine], 2001, no. 12, pp. 54-60. (In Russian).

15. Istoriya i kultura Vyatskogo kraya [History and Culture of the Vyatka Region]. Moscow: Akademichesky Proyekt: Konstanta Publ., 2005. (In Russian).

16. 16.Kulikov K.I. (ed.) Istoriya Udmurtii: Konets XV - nachalo XX veka [History of Udmurtia: The end of $15^{\text {th }}-$ the beginning of $20^{\text {th }}$ century]. Izhevsk: UIIYaL RAN [Udmurt Institute of History, Language and Literature of the Ural Branch of the Russian Academy of Sciences], 2004. (In Russ.).

17. Kationov O.N. Moskovsko-Sibirsky trakt i ego zhiteli v XVII-XIX vv. [Moscow-Siberian tract and its inhabitants in the 17th-19th centuries]. Novosibirsk, 2004. (In Russian).

18. Koshkareva A.M. Ocherki sibirskoy slovesnosti. Uchebnoye posobiye [Essays on Siberian Literature. Study Guide]. Nizhnevartovsk: Nizhnevartovsk Humanitarian University Publ., 2010. (In Russian).

19. Mosin A.G. Istoricheskiye korni uralskikh family [Historical Roots of the Urals' Surnames]. Ekaterinburg: Goshitsky Publ., 2008. (In Russian).

20. Oborin V.A. Zaseleniye i osvoeniye Urala v kontse XI - nachale XVII veka. [Settlement and development of the Urals in the late 11th - early 17th centuries]. Irkutsk: Irkutsk University Publ., 1990. (In Russian).

21. Pamyatniki delovoy pismennosti XVII v. Vladimirskiy krai. [Literary Business Manuscripts of the XVII Century. Vladimirsky Krai]. Kotkov S.I. (ed.). Moscow: Nauka Publ., 1984. (In Russian).

22. Pamyatniki delovoy pismennosti XV-XVII vv. Ryazansky krai. [Literary Business Manuscripts of the XV-XVII Centuries. Ryazansky Krai]. Kotkov S.I. (ed.). Moscow: Nauka Publ., 1978. (In Russian).

23. Pamyatniki yuzhnovelikorusskogo narechiya. Konets XVI - nachalo XVII v. [Manuscripts of the South-Russian Dialect. The End of the XVI - the Beginning of the XVII Century]. Kotkov S.I. (ed.). Moscow: Nauka Publ., 1990. (In Russian).

24. Pamyatniki yuzhnovelikorusskogo narechiya. Otkazniye knigi. [Manuscripts of the South-Russian Dialect. Allotment Books]. Kotkov S.I. (ed.). Moscow: Nauka Publ., 1977. (In Russian).

25. Pamyatniki yuzhnovelikorusskogo narechiya. Tamozhenniye knigi. [Manuscripts of the South-Russian Dialect. Customs Books]. Kotkov S.I. (ed.). Moscow: Nauka Publ., 1982. (In Russian).

26. Pochta [Post Office]. Entsiklopedichesky slovar'. T.48. [Encyclopedic dictionary. Vol. 48]. Brokgauz F.A., Efron I.A. (eds.). St. Petersburg, 1898, pp. 792-819. (In Russian).

27. Slovar russkikh narodnykh govorov [Dictionary of Russian Folk Dialects]. Moscow, St. Petersburg: $1965-2016$. Vol. 1-49. (In Russian).

28. Slovar russkogo yazyka XI-XVII vv. [Dictionary of the Russian Language of the XI-XVII Centuries]. No 1-30. Moscow, Nauka Publ., 1975-2015. (In Russin).

29. Slovar russkogo yazyka XVIII v. [Dictionary of the Russian Language of the XVIII Century]. No. 1-22. Leningrad, St. Petersburg Publ., 1984-2019. (In Russian).

30. Sreznevskiy I.I. Materialy dlya slovarya drevnerusskogo yazyka po pismennyam pamyatnikam [Materials for the dictionary of the Old Russian language based on written records]. St. Petersburg, 1983. (In Russian).

31. Strashova A.P., Parail A.V. Konnotatsii obraza yamshchika v russkoy kulture [Connotations of the image of the coachman in Russian culture]. Verkhnevolzhsky filologichesky vestnik [Verkhnevolzhsky philological bulletin], no. 2, 2018. (In Russian).

32. Suffiksalnoye slovoobrazovaniye sushchestvitelnykh v vostochnoslavyanskikh yazykakh 15-17 vv. [Suffixal word formation of nouns in the Eastern Slavic languages of the $15^{\text {th }}-17$ th centuries]. Moscow: Nauka Publ., 1974. (In Russian).

33. Torgovlya [Trade]. Entsiklopedichesky slovar'. T.66. [Encyclopedic dictionary. Vol. 66]. Brokgauz F.A., Efron I.A. (eds.). St. Petersburg, 1901, pp. 541-587. (In Russian).

34. Ushakov D.N. Tolkovyi slovar russkogo yazyka [Explanatory Dictionary of the Russian Language]: In 4 Volumes. Moscow, 1935-1940. (In Russian).

35. Fasmer M. Etimologicheskiy slovar russkogo yazyka [Etymology Dictionary of the Russian Language]: In 4 Volumes. Moscow: Astrel’ Publ., 2009. (In Russian). 
36. Khitrova V.I. Dopolneniya k 'Slovaryu russkogo yazyka XI-XVII vv.' [Additions to the 'Dictionary of the Russian language of the XI-XVII centuries']. Problemy razvitiya yazyka [Language Development Issues]. Saratov: Saratov University, 1981, pp. 137-140. (In Russian).

37. Chernykh P.Ya. Ocherk russkoy istoricheskoy leksikologii. Drevnerussky period [Essay on Russian Historical Lexicology. Old Russian period]. Moscow: Moscow University Publ., 1956. (In Russian).

38. Chernykh P.Ya. Istoriko-etimologicheskiy slovar sovremennogo russkogo yazyka: 13560 slov [Historical and Etymological Dictionary of the Modern Russian Language: 13560 Words] Vol. 1-2. Moscow: Russian Language Publ., 1994. (In Russian).

39. Chichagov V.K. Iz istorii russkikh imyon, otchestv i familiy [From the History of Russian Names, Patronymics and Surnames]. Moscow: State Publishing House of Educational and Pedagogical Literature, 1959. (In Russian).

40. Shansky N.M., Ivanov V.V., Shanskaya T.V. Kratkiy etimologichesky slovar' russkogo yazyka [Concise Etymology Dictionary of the Russian Language]. Moscow: Prosveshcheniye Publ., 1975. (In Russian).

41. Etimologichesky slovar slavyanskikh yazykov. Praslavyansky leksicheskiy fond [Etymological Dictionary of the Slavic Languages. The Proto-Slavic Lexicon]. Trubachev O.N., Zhuravlev A.F. (eds.), no. 1-41. Moscow: Nauka Publ., 1974-2018. (In Russian).

42. Yamskaya povinnost' [Coachman's servitude]. Entsiklopedichesky slovar'. T. 82. [Encyclopedic dictionary. Vol. 82]. Brokgauz F.A., Efron I.A. (eds.). St. Petersburg, 1904. P. 664. (In Russian).

43. Yamskaya sloboda [Coachman's settlement]. Entsiklopedichesky slovar'. T. 82. [Encyclopedic dictionary. Vol. 82]. Brokgauz F.A., Efron I.A. (eds.). St. Petersburg, 1904. P. 664. (In Russian).

Received 28.05.2021

Sheidayeva S.G., Doctor of Philology, Professor

Udmurt State University

Universitetskaya st., 1/2, Izhevsk, Russia, 426034

E-mail: Sheidaeva@mail.ru 